Creative Commons User License: CC BY-NC-ND

Abstracted by: EBSCOhost, Electronic Journals Service (EJS),

Google Scholar, Journal Seek, Scientific Commons,

Food and Agricultural Organization (FAO), CABI and Scopus

http://eoi.citefactor.org/10.11226/v25i3
Journal of Agricultural Extension

Vol. 25 (3) July, 2021

ISSN(e): 24086851; ISSN(Print); 1119944X

http://journal.aesonnigeria.org

http://www.ajol.info/index.php/jae

Email: editorinchief@aesonnigeria.org

\title{
Information Needs of Cassava Farmer-Processors on Cassava Value Addition Technologies in Oyo State, Nigeria
}

https://dx.doi.org/10.4314/jae.v25i3.4

\section{Olajide, Rasak B.}

Department of Agricultural Extension and Rural Development, Faculty of Agriculture, University of Ibadan, Nigeria. Email: r.olajide@gmail.com ;Phone: +234 8034077794

Corresponding Author

\section{Sanni, Lateef. 0.}

International Institute of Tropical Agriculture (IITA), Ibadan, Nigeria.

Email: I.sanni@cgiar.org; Phone: +234 8033469882

\section{Atser, Godwin.}

International Institute of Tropical Agriculture (IITA), Ibadan, Nigeria.

Email: g.atser@cgiar.org; Phone: +234 8039784453

\section{Dixon, Alfred}

International Institute of Tropical Agriculture (IITA), Ibadan, Nigeria. Email:a.dixon@cgiar.org;

Phone: +234 8034576082

Oladokun, Ibukunoluwa. 0.

International Institute of Tropical Agriculture (IITA), Ibadan, Nigeria. Email: i.oladokun@cgiar.org Phone: +234 7038513662

\section{Abstract}

This study investigated the information needs of cassava farmer-processors on cassava value addition technologies in Oyo State, Nigeria, to ascertain areas of information gap for farmers to maximally exploit the opportunities inherent in the product value addition. Using a multistage sampling procedure, 130 registered cassava farmer-processors were sampled and interviewed. Data were collected on respondents' enterprise characteristics, access to information, perceived benefits and constraints to accessing information and information needs on cassava value addition. Data were analysed using percentage, mean and correlational analysis at $p=0.05$. Results reveal that respondents had farm size and farming experience of 2.3 ha and 20.1 \pm 13.8 years, respectively, while income was $\$ 273,784.6 \pm \$ 458281.3$. Though respondents were constrained with low income (70.0\%), they reckoned that if they had access to information on value addition, their postharvest loss would be reduced (89.2\%). Respondents had information gap on information needs on value addition technologies for producing cassava adhesives $\left(1^{\text {st }}\right)$, glucose syrups $\left(2^{\text {nd }}\right)$ and confectionaries $\left(3^{r d}\right)$. Farming experience $(r=-.236)$, constraints $(r=-.288)$ and access to sources of information were significantly related to respondents' information needs. It is recommended that information on improved cassava value addition technologies be made available to cassava farmers through relevant sources, especially during emergencies coupled with hands -on training for effective application of information acquired.

Keywords: Information needs on cassava value chain, Information sources on cassava value chain, Cassava value addition technologies. 
Creative Commons User License: CC BY-NC-ND

Abstracted by: EBSCOhost, Electronic Journals Service (EJS),

Google Scholar, Journal Seek, Scientific Commons,

Food and Agricultural Organization (FAO), CABI and Scopus

http://eoi.citefactor.org/10.11226/v25i3
Journal of Agricultural Extension

Vol. 25 (3) July, 2021

ISSN(e): 24086851; ISSN(Print); 1119944X

http://journal.aesonnigeria.org

http://www.ajol.info/index.php/jae

Email: editorinchief@aesonnigeria.org

\section{Introduction}

Cassava, Manihot esculenta Grantz (Euphorbiaceae) is very important, not just as a food crop but as a major source of income to over 800 million people in the world (Anyanwu, Ibeto Ezeoha \& Ogbuagu, 2015).Total world cassava demand would reach 275 million tonnes by 2020 (Njukwe, Rachid, Papa, Araki, Holger, Andre, Thomas \& Abdou, 2014), while Africa now produces about $61 \%$ of the total world production with a projection that by the year 2025, about $62 \%$ of global cassava production will be from sub-Saharan Africa. Nigeria is the largest producer of the crop in the world with output level of 59.1 million tonnes (Food and Agricultural Organization Statistics (FAOSTAT), 2020).

Apart from the primary uses of cassava roots, there are a lot of other uses and benefits that cassava can be put to, through value addition. Akinwalere, Adeleke and Ojo (2016) reported that cassava ranks very high among crops that convert the greatest amount of solar energy into soluble carbohydrates per unit of area. The crop is a competitive crop especially for the production of starch. It can also be processed into flour which can further be used for food products like glucose for pharmaceutical products as well as food supplements to make alcohol and other beverages (Ani, Ojila, \& Abu 2019). All these emphasize the potentials of cassava in food security and poverty alleviation, through value addition.

In spite of the leading position of Nigeria in the production of the crop, the country still imports significant quantities of cassava products such as starch, flour, sweeteners that can be obtained locally from cassava. Industrial users of cassava products in the country consist mainly of bakeries, flour mills, livestock and pharmaceutical firms. Sanusi (2012) in Ajayi and Opeyemi, (2018), reported that enormous foreign exchange resources have been utilized for the importation of various raw materials for the manufacturing sector over the years. This constituted a drain on the foreign exchange resources of the country. What is more worrisome is that a good proportion of these raw materials can be sourced locally from agricultural produce.

The need for diversification and expansion of cassava development into new growth markets, have attracted considerable research interests of governmental and nongovernmental organizations. In view of the wide cultivation and potential benefits derivable from cassava, the Presidential Cassava Initiative was introduced in 2002 with the primary objective of expanding primary processing and utilization to absorb the national cassava production glut among others. Furthermore, the recent Agricultural Transformation Programme of the federal government has facilitated the establishment of cassava processing plants. Arising from this, cassava chips exportation has been achieved. This has led to increase in the interest of rural famers to increase their level of cassava production and processing into various products such as cassava flour, Garri, chips, starch and High-Quality Cassava Flour (HQCF) which is bio - fortified with Vitamin A. The HQCF is commonly used in processing of snacks, biscuits, cakes and other confectioneries to meet increasing demand from urban consumers. These rapidly 
Creative Commons User License: CC BY-NC-ND

Abstracted by: EBSCOhost, Electronic Journals Service (EJS),

Google Scholar, Journal Seek, Scientific Commons,

Food and Agricultural Organization (FAO), CABI and Scopus

http://eoi.citefactor.org/10.11226/v25i3
Journal of Agricultural Extension

Vol. 25 (3) July, 2021

ISSN(e): 24086851; ISSN(Print); 1119944X

http://journal.aesonnigeria.org

http://www.ajol.info/index.php/jae

Email: editorinchief@aesonnigeria.org

expanding end-use markets for cassava are creating real opportunities for a boom in the processing of cassava roots into various value-added forms.

Consequently, research institutes, namely; Product Development Agency (PRODA), Federal Institute of Industrial Research (FIIRO) and International Institute of Tropical Agriculture (IITA) have developed many mechanized units designed to remove the constraints that cassava processors face (Ewebiyi, Ikotun and Olayemi 2020). Ewebiyi et al. (2020) noted that several models and variations of mechanical cassava graters, pressers and sifters are available in the market. Through these broad-based projects and research activities, a lot of technical knowledge and information about cassava value addition has been generated. The technical knowledge and information constitute recommendation packages that the state-wide Agricultural Development Programmes (ADP) have been mandated to disseminate in fulfillment of their statutory role and due to their direct access to farmers.

In spite of this treasure of knowledge and information about cassava processing and value addition, Umeh (2015) alluded that most cassava producers lack sufficient information about post-harvest technologies and other information needed to successfully maximize the economic potentials of the crop. For cassava farmers to embrace these innovations, it therefore becomes sacrosanct to increase their awareness of the benefits associated with processing cassava into value-added products through proven technologies as Olajide and Olonibua (2019) also noted that for farmers in general to transit from their traditional production systems to a more advanced and commercialized system of production, they need adequate agricultural information on modern technologies, especially value addition. Moreover, the lack of knowledge on how to add value through proper storage, processing and marketing impedes agricultural growth. There is, therefore, a need to improve the level of farmers' knowledge and information on value addition. It is against this backdrop that this study:

1. profiled cassava farmer-processors based on their socioeconomic characteristics;

2. investigated access to sources of information on cassava value addition;

3. assessed the level of access to available information on cassava value addition technologies;

4. documented benefits of adequate access to this information

5. highlighted constraints to information on cassava value addition technologies; and

6. ascertained the needs of cassava famer-processors on cassava value addition technologies. 
Creative Commons User License: CC BY-NC-ND

Abstracted by: EBSCOhost, Electronic Journals Service (EJS),

Google Scholar, Journal Seek, Scientific Commons,

Food and Agricultural Organization (FAO), CABI and Scopus

http://eoi.citefactor.org/10.11226/v25i3
Journal of Agricultural Extension

Vol. 25 (3) July, 2021

ISSN(e): 24086851; ISSN(Print); 1119944X

http://journal.aesonnigeria.org

http://www.ajol.info/index.php/jae

Email: editorinchief@aesonnigeria.org

\section{Methodology}

This study area was Oyo State. Oyo state covers approximately an area of 28,454 square kilometers and is ranked $14^{\text {th }}$ by size with latitude; $8.1574^{\circ} \mathrm{N}$ and longitude; $3.6147^{\circ} \mathrm{E}$.

A multistage sampling procedure was used for this study. The study targets were cassava farmers who are also into processing. The first stage involved random selection of two (Oyo and Saki) out of the four ADP zones in the state. In the second stage, a block was randomly selected from the two zones making a total of two blocks. Thirdly, two cells were randomly selected from each block to give a total of four cells. Lastly, 162 cassava farmer-processors (representing $5 \%$ of the total 3,255 cassava farmerprocessors) were sampled proportionate to size from the four cells. Only 130 returned completely filled instruments used for data analysis. Primary data was used in this study. Interview schedule was used to elicit responses from the respondents. The items on the instrument were informed by the study objectives. Instrument for data collection was validated using face validity by discussing the contents and objectives of the study with the experts in the agricultural extension and rural development. Both dependent and independent variables were measured in this study. The dependent variables; information needs of the cassava farmer-processors on cassava value addition technologies was measured by providing a list of cassava value addition technologies. Respondents were asked to rate these technologies based on their information needs on a four-point rating scale of highly needed, moderately needed, lowly needed and not needed. The response options were assigned scores of 3, 2, 1 and 0 , respectively. Maximum and minimum scores of 42 and 17were generated and the total scores for each and for all respondents were calculated. Thereafter, the mean score of 31.17 was obtained and that formed the basis of categorization of respondents into high and low information needs on value addition. Respondents with scores above the mean were ranked as having high information needs and those below the mean were ranked as having low information needs. Data were analyzed and presented in both descriptive and inferential statistics using frequencies, percentage, mean and Pearson product moment correlation at $\mathrm{p}-0.05$.

\section{Results and Discussion}

\section{Socioeconomic characteristics}

The respondents had $20.1 \pm 13.8$ years of farming experience (Table 1) with $39.2 \%$ having between 15 to 28 years. This corroborates the findings of Ogunyinka and Oguntuase (2020) who reported similar findings in their study. With this vast experience and with the knowledge that comes with it, farmers may be prompted to seek information on improved value addition technologies that would primarily boost their cassava enterprise, increase their income and ultimately reduce postharvest loss of cassava. Farming experience is expected to influence the adoption of cassava value addition technologies. It is either that the accumulated years of experience will make them highly receptive or unreceptive to the innovations. Although, Mordiwa (2019) reported in a 
Creative Commons User License: CC BY-NC-ND

Abstracted by: EBSCOhost, Electronic Journals Service (EJS), Google Scholar, Journal Seek, Scientific Commons,

Food and Agricultural Organization (FAO), CABI and Scopus
Journal of Agricultural Extension

Vol. 25 (3) July, 2021

ISSN(e): 24086851; ISSN(Print); 1119944X

http://journal.aesonnigeria.org

http://www.ajol.info/index.php/jae

Email: editorinchief@aesonnigeria.org

http://eoi.citefactor.org/10.11226/v25i3

similar study that farming experience had no effect on farmers' access to agricultural information. Larger proportion of farmers had formal education (92.3\%) prompting more eagerness to seek and utilize information on cassava value addition technologies to improve their production enterprise. This is corroborated by Mordirwa (2019), that the attainment of education is essential for the assessment of agricultural information intake or access by farmers. It will be very difficult for a farmer who cannot read to access agricultural information in print media. Other researchers (Dhehibi, Rudiger, Moyo, \& Dhraief; 2020) have also observed that literacy aids access to information and adoption. Table 1 further reveals that most respondents were small-scale farm holders, cultivating 3.7 hectares of land or less, with an average annual income of 274,000 or less worth of local currency-approximately $\$ 700$ per year-for more than one-third of the farmers and about three percent earning between $\$ 1300$ and $\$ 2,500$ per year. 
Creative Commons User License: CC BY-NC-ND

Abstracted by: EBSCOhost, Electronic Journals Service (EJS), Google Scholar, Journal Seek, Scientific Commons,

Food and Agricultural Organization (FAO), CABI and Scopus

http://eoi.citefactor.org/10.11226/v25i3
Journal of Agricultural Extension

Vol. 25 (3) July, 2021

ISSN(e): 24086851; ISSN(Print); 1119944X

http://journal.aesonnigeria.org

http://www.ajol.info/index.php/jae

Email: editorinchief@aesonnigeria.org

Table 1: Socio - economic characteristics

Socio-economic variables

\section{Farming Experience}

$1-14$

$15-28$

$29-42$

$43-56$

$>56$

\section{Level of education}

No formal education

Primary

Secondary

Tertiary

\section{Farm size}

$0.4-3.4$

$3.5-6.5$

$6.6-9.6$

$9.7-12.7$

$12.8-15.8$

$15.9-18.9$

$19-22$

$23-26$

$27-30$

\section{Estimated yearly}

income (

$48,000-506,280$

$506,281-964,561$

$964,562-1,422,842$

$>1,422,843$
34.6

39.2

19.2

6.2

0.8

\section{7}

36.9

33.1

22.3

83.8

12.3

0.0

1.5

0.8

0.0

0.0

0.8

0.8
$20.1 \pm 13.8$

Mean / SD

\section{.}


Creative Commons User License: CC BY-NC-ND

Abstracted by: EBSCOhost, Electronic Journals Service (EJS),

Google Scholar, Journal Seek, Scientific Commons,

Food and Agricultural Organization (FAO), CABI and Scopus

http://eoi.citefactor.org/10.11226/v25i3
Journal of Agricultural Extension

Vol. 25 (3) July, 2021

ISSN(e): 24086851; ISSN(Print); 1119944X

http://journal.aesonnigeria.org

http://www.ajol.info/index.php/jae

Email: editorinchief@aesonnigeria.org

of Dhehibi,, Rudiger, Moyo, and Dhraief (2020) where they reported "fellow farmers" and "personal experience" as leading information sources among farmers. In another study, Drafor (2016) referred to radio as one of the best sources of diffusing agricultural, technical and scientific information to farmers.

Table 2: Access to sources of information on cassava value addition technologies

\begin{tabular}{lll}
\hline $\begin{array}{l}\text { Access to information } \\
\text { source }\end{array}$ & Mean & SD \\
\hline Radio & 2.42 & 1.01 \\
Television & 1.49 & 1.02 \\
Newspaper & 0.62 & 0.91 \\
Magazines & 0.48 & 0.85 \\
Extension agents & 2.58 & 0.72 \\
Internet & 0.81 & 1.16 \\
Books & 0.81 & 1.13 \\
Seminars & 2.46 & 0.88 \\
Fellow farmers & 2.57 & 0.76 \\
Friends & 2.41 & 0.87 \\
Traders & 1.52 & 0.84 \\
Community leaders & 0.75 & 1.04 \\
Cooperative groups & 1.16 & 1.12 \\
\hline
\end{tabular}

Source: Field survey, 2019

\section{Level of Access to Available Information on Cassava Value Addition Technologies}

Table 3 presents results on the level of access to information on cassava value addition technologies. While information on technologies for Garri, Lafun and odourless fufu, were fully accessed with ranking order of $1^{\text {st }}, 2^{\text {nd }}, 3^{\text {rd }}$ respectively, farmers had low and no access to information on value addition technologies for products such as glucose syrups $14^{\text {th }}$, cassava adhesives $13^{\text {th }}$, ethanol $11^{\text {th }}$, and HQCF $10^{\text {th }}$. Other cassava value addition technologies were only partially accessed. This result is consistent with Falola et al (2014) who reported Garri and fufu to be the major value-added products produced by cassava farmers. This only proves that a lot of cassava farmers are still at the level of the age long traditional and conventional uses of cassava and are not in sync with new and improved cassava value addition technologies. Overall, $50.8 \%$ and $49.2 \%$ had high and low access to information on cassava value addition technologies. Obviously, an agricultural information targeting the rural farmers will not achieve its purpose if put in magazines or publications. Thus, to enhance the production and productivity of agriculture, farmers should have access to well organize and relevant information and proper and sufficient utilization of agricultural information requires good facilitation (Olajide, Adeniyi and Ladigbolu, 2015). 
Creative Commons User License: CC BY-NC-ND

Abstracted by: EBSCOhost, Electronic Journals Service (EJS), Google Scholar, Journal Seek, Scientific Commons,

Food and Agricultural Organization (FAO), CABI and Scopus

http://eoi.citefactor.org/10.11226/v25i3
Journal of Agricultural Extension

Vol. 25 (3) July, 2021

ISSN(e): 24086851; ISSN(Print); 1119944X

http://journal.aesonnigeria.org

http://www.ajol.info/index.php/jae

Email: editorinchief@aesonnigeria.org

Table 3: Distribution of respondents by access to information on cassava value addition technologies

\begin{tabular}{lccc}
\hline $\begin{array}{l}\text { Access to information on value } \\
\text { addition technologies for: }\end{array}$ & Mean & SD & Rank \\
& & & \\
\hline Cassava flakes & 1.84 & 0.48 & $1^{\text {st }}$ \\
Lafun & 1.75 & 0.47 & $2^{\text {nd }}$ \\
Odourless fufu & 1.63 & 0.54 & $3^{\text {rd }}$ \\
Starch & 1.52 & 0.56 & $4^{\text {th }}$ \\
Chips for feed-millers & 1.52 & 0.64 & $4^{\text {th }}$ \\
Cassava chips & 1.09 & 0.80 & $6^{\text {th }}$ \\
Tapioca & 0.86 & 0.80 & $7^{\text {th }}$ \\
Vegetables & 0.70 & 0.75 & $8^{\text {th }}$ \\
Confectionaries & 0.65 & 0.75 & $9^{\text {th }}$ \\
HQCF & 0.60 & 0.70 & $10^{\text {th }}$ \\
Ethanol & 0.42 & 0.69 & $11^{\text {th }}$ \\
Abacha & 0.42 & 0.67 & $11^{\text {th }}$ \\
Cassava adhesives & 0.40 & 0.72 & $13^{\text {th }}$ \\
Glucose syrups & 0.28 & 0.57 & $14^{\text {th }}$ \\
\hline
\end{tabular}

Source: Field survey, 2019

\section{Benefits of Access to Information on Cassava Value Addition Technologies}

Table 4 shows that the respondents affirmed that all the stated benefits as highly beneficial, while only an insignificant number rated increased marketing networks, increased productivity and extended shelf life $(0.8 \%$, respectively) as not beneficial to them even if they had adequate access to information on cassava value addition technologies. Reduced postharvest loss, increased production scale and increased income ranked $1^{\text {st }}, 2^{\text {nd }}$ and $3^{\text {rd }}$, respectively on the list of highly beneficial. This confirms the submissions of Kehinde and Aboaba's study (2016) that alluded to the fact that the rationale for value addition is predicated on the need to increase rural incomes, employment and investment opportunities.

Table 4: Benefits of access to information on cassava value addition technologies

\begin{tabular}{lccc}
\hline Benefits & Mean & SD & Rank \\
\hline Reduced postharvest loss & 2.89 & 0.31 & $1^{\text {st }}$ \\
Increased scale of production & 2.80 & 0.41 & $2^{\text {nd }}$ \\
Increased income & 2.78 & 0.49 & $3^{\text {rd }}$ \\
Increased productivity & 2.77 & 0.51 & $4^{\text {th }}$ \\
Increased marketing network & 2.73 & 0.57 & $5^{\text {th }}$ \\
Extended shelf life & 2.70 & 0.63 & $6^{\text {th }}$ \\
\hline
\end{tabular}

Source: Field survey, 2019 
Creative Commons User License: CC BY-NC-ND

Abstracted by: EBSCOhost, Electronic Journals Service (EJS),

Google Scholar, Journal Seek, Scientific Commons,

Food and Agricultural Organization (FAO), CABI and Scopus
Journal of Agricultural Extension

Vol. 25 (3) July, 2021

ISSN(e): 24086851; ISSN(Print); 1119944X

http://journal.aesonnigeria.org

http://www.ajol.info/index.php/jae

Email: editorinchief@aesonnigeria.org

\section{Constraints in Accessing Information on Cassava Value Addition Technologies}

Table 5 presents findings on constraints encountered by cassava farmer-processors in accessing information on cassava value addition technologies. Low level of income, illiteracy and inability to access formal channel of information were rated the most severe constraints in that order, while lack of personal interest ranked $5^{\text {th }}$ and was adjudged mild constraint and inadequate extension contact ranked least $\left(7^{\text {th }}\right)$ on the list. The availability of extension agents in relation to the apathy expressed in access to cassava value addition technologies could mean that extension agents either lack latest agricultural information or are not equipped with the right facilities to transmit advanced innovations to farmers, conduct demonstrations and workshops that could promote and encourage adoption by farmers. Abou (2015) observed that the missing link between research and sustained productions is lack of effective service delivery services. There is a wide gap between available knowledge of improved technology (Abou, 2015) and actual practice and this has had a considerable effect on the attempt at increasing food production. Thus, emphasis was made on the need to provide effective information service delivery in all aspects of their farm enterprise, including value addition to cassava farmers in Nigeria (Afolami, Obayelu, \& Vaughan, 2015).

Table 5: Constraints in accessing information on cassava value addition technologies

\begin{tabular}{|c|c|c|}
\hline Constraint & $\begin{array}{l}\text { Mea } \\
\mathrm{n}\end{array}$ & SD \\
\hline Illiteracy & 1.52 & 0.71 \\
\hline Low level of income & 1.60 & 0.65 \\
\hline Lack of power supply & 1.52 & 0.66 \\
\hline Lack of personal interest & 1.26 & 0.65 \\
\hline $\begin{array}{l}\text { Inability to access formal } \\
\text { channel of information }\end{array}$ & 1.57 & 0.62 \\
\hline $\begin{array}{l}\text { Inadequate } \quad \text { extension } \\
\text { contacts }\end{array}$ & 0.57 & 0.75 \\
\hline $\begin{array}{l}\text { Incomplete or irrelevant } \\
\text { information }\end{array}$ & 1.23 & 0.77 \\
\hline
\end{tabular}

Source: Field survey, 2019

\section{Information Needs of Cassava Famer-Processors on Cassava Value Addition Technologies}

Findings in Table 6 reveal that information needs on cassava value-addition technologies for adhesives $\left(1^{\text {st }}\right)$, glucose syrups $\left(2^{\text {nd }}\right)$, confectionaries $\left(3^{\text {rd }}\right)$, HQCF $\left(4^{\text {th }}\right)$ were high, but low for cassava flakes - Garri and Lafun $\left(13^{\text {th }}\right)$, as well as odourless fufu $\left(12^{\text {th }}\right)$. This again confirms the findings above that cassava farmers are still lagging behind in 
Creative Commons User License: CC BY-NC-ND

Abstracted by: EBSCOhost, Electronic Journals Service (EJS), Google Scholar, Journal Seek, Scientific Commons,

Food and Agricultural Organization (FAO), CABI and Scopus

http://eoi.citefactor.org/10.11226/v25i3
Journal of Agricultural Extension

Vol. 25 (3) July, 2021

ISSN(e): 24086851; ISSN(Print); 1119944X

http://journal.aesonnigeria.org

http://www.ajol.info/index.php/jae

Email: editorinchief@aesonnigeria.org

improved technologies that would have otherwise pivoted their productivity to the international markets. This is further confirmed by Okumu and Obora (2013) who noted that rural farmers face widening information gaps and therefore it is difficult for them to compete in the global market or even adopt improved technology. Information needs on cassava value addition technologies was high for $50.8 \%$ of the respondents, while it was low for $49.2 \%$. All the respondents expressed high knowledge to the most conventional uses of cassava but little or nothing is known about the improved cassava value addition technologies even those that are aware of the existence of such improved technologies lacked in - depth practical knowledge of how to put it to efficient use to better their lot. Thus, it becomes imperative to create more awareness through the right communication channels and as well facilitate necessary demonstration and workshops to cassava farmers on latest value-added technologies. Okumu and Obora (2013) emphasized that, now more than ever, information dissemination is crucial in enhancing and developing the adaptive capacities of all economies especially in rural areas to adopt new agricultural concepts. Information was categorized as one of the chief determinants of the progress of nations, communities and individual (Sanap, 2015).

Table 6: Information needs on cassava value addition technologies

\begin{tabular}{llll}
\hline Value added technologies for: & Mean & SD & Rank \\
\hline & & & \\
Cassava adhesives & 1.99 & 0.58 & $1^{\text {st }}$ \\
Glucose syrups & 1.85 & 0.57 & $2^{\text {nd }}$ \\
Confectionaries & 1.83 & 0.54 & $3^{\text {rd }}$ \\
HQCF & 1.72 & 0.66 & $4^{\text {th }}$ \\
Ethanol & 1.67 & 0.64 & $5^{\text {th }}$ \\
Vegetables & 1.29 & 0.80 & $6^{\text {th }}$ \\
Cassava chips & 1.08 & 0.85 & $7^{\text {th }}$ \\
Tapioca & 0.77 & 0.75 & $8^{\text {th }}$ \\
Animal feed & 0.68 & 0.75 & $9^{\text {th }}$ \\
Starch & 0.58 & 0.69 & $10^{\text {th }}$ \\
Cassava flakes & 0.49 & 0.66 & $11^{\text {th }}$ \\
Odourless fufu & 0.45 & 0.58 & $12^{\text {th }}$ \\
Lafun & 0.42 & 0.68 & $13^{\text {th }}$ \\
Abacha & 0.38 & 0.48 & $14^{\text {th }}$ \\
Overall information need & & & \\
High & 66 & 50.8 & \\
Low & 64 & 49.2 & \\
Total & 130 & 100 & \\
\hline
\end{tabular}

Source: Field survey, 2019 
Creative Commons User License: CC BY-NC-ND

Abstracted by: EBSCOhost, Electronic Journals Service (EJS),

Google Scholar, Journal Seek, Scientific Commons,

Food and Agricultural Organization (FAO), CABI and Scopus

http://eoi.citefactor.org/10.11226/v25i3
Journal of Agricultural Extension

Vol. 25 (3) July, 2021

ISSN(e): 24086851; ISSN(Print); 1119944X

http://journal.aesonnigeria.org

http://www.ajol.info/index.php/jae

Email: editorinchief@aesonnigeria.org

\section{Correlation between Cassava Farmers' Personal Characteristics and Information Needs}

Table 7 indicates that respondents' age $(r=-.148$; household size $(r=-.141$, estimated yearly income $(r=.015$,); farm size $(r=.089$, ) and years of formal education $(r=.038$, $)$ had no significant relationship with information needs, while farming experience $(r=-$ .236,) was significantly $(P \leq 0.05)$ related, although negatively. This could mean that the greater the wealth of experience, the more the need for more information diminished. Farmers with lower farming experience still have fresh minds and are yearning for more information unlike the more experienced farmers who may likely feel they have seen and known it all or might have over the years become satisfied with the status quo and are not enthusiastic towards new technologies. This is similar to the finding of Drafor (2016) who opined that the younger farmers would most likely be willing to spend more time to obtain information on improved technologies compared to the old farmers. However, this contradicts findings in a similar study by Modirwa (2019).

Table 7: Relationship between socio - economic characteristics and information needs

\begin{tabular}{ll}
\hline $\begin{array}{l}\text { Socio } \\
\text { variable }\end{array}$ & economic \\
\hline Age & -0.148 \\
Household size & -0.141 \\
Farming experience & $-0.236^{*}$ \\
Farm size & 0.089 \\
Years of formal education & 0.038 \\
Estimated yearly income & -0.015 \\
\hline
\end{tabular}

${ }^{*} \mathrm{P} \leq 0.05$

\section{Conclusion and Recommendations}

Casava farmer-processors are mostly served by fellow farmers, radio and extension agents for their enterprise information. Most constraint they grappled with in accessing information they required was low level of income perhaps due to their level of production. Adequate access to value addition information was presumed to be of immense benefit beneficial to their enterprise. They all had full access to information on Garri, Lafun and Fufu but lacked adequate information about new and improved value addition technologies.

Government and private organizations transmitting agricultural information should target the most accessed information sources by farmers namelyradio and extension agents in disseminating important information to them.

Multiple information sources should be employed in disseminating cassava value addition information to farmers. 
Creative Commons User License: CC BY-NC-ND

Abstracted by: EBSCOhost, Electronic Journals Service (EJS), Google Scholar, Journal Seek, Scientific Commons,

Food and Agricultural Organization (FAO), CABI and Scopus

http://eoi.citefactor.org/10.11226/v25i3
Journal of Agricultural Extension

Vol. 25 (3) July, 2021

ISSN(e): 24086851; ISSN(Print); 1119944X

http://journal.aesonnigeria.org

http://www.ajol.info/index.php/jae

Email: editorinchief@aesonnigeria.org

Extension agents should put more efforts towards organizing hands - on training to farmers on cassava value addition technologies in order to make effective the disseminated information.

\section{References}

Abou B. (2015) Extension and Advisory Services Rural Extension Services for Agricultural Transformation. Technical paper, Feeding Africa Conference 21-23 October 2015

Afolami, C. A., Obayelu, A. E., \& Vaughan, I. I. (2015). Welfare impact of adoption of improved cassava varieties by rural households in South Western Nigeria. Journal of Agricultural and Food Economics, 3(18): 72

Ajayi O.O., and Opeyemi F.O., (2018). Impact assessment of cassava cottage industry project on

rural farmers in Nigeria: A Case Study of Kogi State. International Journal of Current Research in Life Sciences Vol. 07, No. 9, pp.2722-2724.

Akinwalere B. O., Adeleke M. L., and Ojo A. O. (2016) Appraisal of the Level of Awareness and

Adaptation to Climate Change on Cassava Production in Ondo State, Nigeria. Journal of Scientific Research \& Reports 10(4): 1-6, 2016

Ani D.P., Ojila H., and Abu O. (2019). Profitability of Cassava Processing: A Case Study of Otukpo Lga, Benue State, Nigeria. Journal of Sustainable Food Production Vol. 6, pp 12-23

Anyanwu, C. N., Ibeto, C. N., Ezeoha, S. L., \& Ogbuagu, N. J. (2015). Sustainability of cassava (Manihot esculenta Crantz ) as industrial feedstock, energy and food crop in Nigeria. Journal of Renewable Energy, 81, 745-752.

Dhehibi, B., Rudiger, U., Moyo, H. P., and Dhraief, M. Z. (2020). Agricultural technology transfer preferences of smallholder farmers in Tunisia's arid regions. Sustainability (Switzerland), 12(1), 2-18. https://doi.org/10.3390/SU12010421

Drafor, I. (2016). Access to Information for Farm-Level Decision-Making. Journal of Agricultural and Food Information, 17(4), 230-245. https://doi.org/10.1080/10496505.2016.1213170

Ewebiyi, I.O., Ikotun, T.O., and Olayemi, O.O. (2020). Constraints to utilization of improved processing technologies among cassava processors in Oyo state, Nigeria. Journal of Science \& Sustainable Development I Vol 7 . No 1, . 41 - 49

Falola A., Oyinbo O., Adebayo S.A., Jonathan A., and Jimoh J.O., (2014). Determinants of value addition to cassava in Kwara state, Nigeria. University of Mauritius Research Journal 4(22):245-259

Food and Agricultural Organization Statistics (FAOSTAT), 2020). Food and Agricultural Organization (2020). http://www.fao.org/faostat/en/\#data/QC accessed 17th June, 2021

Kehinde, A.L. and Aboaba, K.O. (2016). Analysis of value addition in the processing of cassava tubers to "garri" among cottage level processors in Southwestern Nigeria. Invited poster presented at the 5th International Conference of the African Association of Agricultural Economists, September 23-26, 2016, Addis Ababa, Ethiopia 
Creative Commons User License: CC BY-NC-ND

Abstracted by: EBSCOhost, Electronic Journals Service (EJS), Google Scholar, Journal Seek, Scientific Commons,

Food and Agricultural Organization (FAO), CABI and Scopus

http://eoi.citefactor.org/10.11226/v25i3
Journal of Agricultural Extension

Vol. 25 (3) July, 2021

ISSN(e): 24086851; ISSN(Print); 1119944X

http://journal.aesonnigeria.org

http://www.ajol.info/index.php/jae

Email: editorinchief@aesonnigeria.org

Mordirwa, S.M. (2019). Effects of farmers' socioeconomic characteristics on access to Agricultural Information in Ngaka Modiri Molewa District of the NorthWest Province. International Journal of Agricultural Extension. 7(01): 1 - 7

Njukwe E., Rachid H., Papa S. S., Araki S., Holger K., Andre M., Thomas N. \& Abdou T. (2014) Cassava value chain development through partnership and stakeholders' platform in Cameroon International Journal of Agricultural Policy and Research Vol.2 (11), 383392

Olajide, B. R., Adenyi, A. and Ladigbolu, T. A. (2015). Viewers' perception of Oju-oja agricultural marketing television programme of Ekiti State Broadcasting Service, Ekiti State, Nigeria. International Journal of Agricultural Economics and Rural Development Vol. 7 (1) $80-87$

Olajide, B. R. and Olonibua, O. O. (2019). Postharvest Information Needs among Plantain Marketers in Southwestern Nigeria Nigerian Journal of Rural Sociology Vol. 19 (1): 6166

Ogunyinka O. and Oguntuase A. (2020) Analysis of cassava production and processing by various groups in support of cassava value chain in the south west of Nigeria. Journal of Food and Agricultural Sciences Vol.9(1), pp. 11-19

Okumu, M., and Obora, M. (2013): Climate Change and the Agricultural Sector: Overview of National and Sectoral Initiatives and Programmes. Ministry of Agriculture, Climate Change Unit. Naivasha

Sanap, K. (2015). Role of Information and Communication Technology in the Women Empowerment. Retrieved from: http://www.nevillewadia.com/images/Cronicle2 015/Dr. Manohar-K.-Sanap15.pdf on 29November 2019. 